\title{
White Educator Perceptions Regarding School Integration: Implication for Multicultural Education
}

\author{
Gregory Alexander \\ Department of Psychology of Education, \\ Faculty of Education, University of the Free State, South Africa \\ alexanderg@ufs.ac.za
}

\section{Doi:10.5901/mjss.2014.v5n4p321}

\section{Abstract}

The admission of learners from various racial backgrounds to integrated schools such as the historically white schools, several challenges became evident. These diverse challenges include amongst others; differences in culture, race, language, ethnicity, norms, habits, home environment, teaching and learning styles, as well as the black learners and white educators having to adapt to the new, diverse classroom situation. Schools have thus become the sites of cultural convergence where previously diverse and divided cultures were to meet for the first time, on supposedly "equal footing". This study reports on white educator perceptions in Northern Cape High schools regarding this integration process and the implication it has for the enhancement of multicultural education. The study has uncovered issues that historically white schools need to consider in addressing the issues and challenges associated with school integration.

Keywords: White educators, school integration, multicultural education, Northern Cape province

\section{Introduction}

The admission of learners from various racial backgrounds to integrated schools such as historically white schools, gave rise to several challenges amongst others, such as the differences in culture, race, language, ethnicity, norms, habits, home environment and teaching and learning styles, as well as learner and educator adaptation to the new, diverse classroom situation (Alexander 2004). Schools became the sites of cultural convergence where people from diverse backgrounds met for the first time, on supposedly 'equal ground'. These cultures, both African and European, although diverse in traditional and historical background, are however similar in their expectations of what quality education entails. Accommodating the aspirations of such a widely diversified learner population presented great challenges to education authorities, schools and educators in particular. Lemmer, Meier and Van Wyk (2006) point out that the management of education is now geographically divided, in contrast to the racially-based departments of education of the past. It is further postulated that in practice, the latter implies that South African educators are now faced with the challenge of teaching increasingly multicultural classes and of implementing school reform programmes, which may change the nature of teaching and learning, so that the needs of all learners may be met.

Despite the differences in learners' informal and formal learning backgrounds, peer interaction and healthy interpersonal relations in cross-cultural groups may provide a constructive basis for harnessing the strengths of different learners and enriching the learning process for all. Kanpol and McLaren (1995) reiterate these sentiments in the following statement: "It is the idea of a common vision or common ground of understanding, that weaves together many different truths or 'truth effects' that has driven us to collectively dialogue across differences".

A brief overview will now be outlined as to give background to the historical context of school integration.

\section{Historical Context as Underpinning for Theoretical Frame}

The historical development of multicultural education in South Africa can only be meaningful assessed against the context of the educational history of the country. Before 1948 a limited mixing of races occurred in certain areas. The official and formal segregation of schools along structured racial and ethnic lines commenced in 1948 when the Nationalist Party seized political control. The racial, ethnic and geographical separations within the education system led to the origin of 17 separate education departments up until 1994 (Naicker 2000). These divisions in education were supported and upheld by apartheid legislation such as the 1953 Bantu Education Act, the 1950 Group Areas Act, the 
1954 Native Resettlement Act, the Reservation of Separate Amenities Act, the Population Registration Act and the Homeland Act (Mda 2000). Prior to 1994, education departments were structured on the basis of race and culture: The Department of Education and Culture, House of Assembly organised schooling for white children; the Department of Education and Culture, House of Delegates organised schooling for Indian children; whilst the Department of Education, House for Representatives and Department of Education and Training, organised schooling for coloured and African children respectively.This separate system of education, characterised by race, class, gender and ethnic divisions (Alexander 2004) resulted in the provision of unequal access to schools, unequal educational opportunities, irrelevant curricula, inadequate infrastructure, facilities and a under qualified educator corps (Kivedo 2007).

From the above mentioned it is evident that all educational change initiatives in post 1994 South Africa were and still are largely driven by imperatives such as overcoming the devastation of apartheid, and the provision of equal, quality education to all citizens within a system that enhances democratic participation, human dignity, equality and social justice, and the redress of imbalances, as well as the empowerment of all citizens (Abdi 2001; Lemmer, Meier \& Van Wyk 2006). Efforts by education authorities to equalise educational schooling opportunities as to promote reconciliation, unity and democratic citizenship was a means to enhance the standard of socio-economic opportunities among all racial and cultural groups in South Africa (Van der Walt 1994). However, it needs to be noted that the severe inequalities caused by the previous apartheid government, coupled with modest economic growth, has precluded the transformation of schools, especially those schools serving historically disadvantaged groups (Lemon 2004). In relation to the latter view Jansen (2005: 283) state that "The problem in South Africa with respect to equal educational opportunities is that complex shifts have taken place in the first decade of democracy that could not have been completely predicted. After 1994 the elite white schools dramatically increased their school fees on grounds that the state's decision to reduce the number of teachers under it's rationalization programme threatened the quality of education in these schools"

Moreover, newly formulated South African education legislation and policy documents such as the South African Constitution (RSA 1996), the South African School (RSA 1996) and the National Education Policy Act (RSA 1996) aimed at the educational change process, all highlighted and affirmed the importance of core values such as respect, human dignity, equality, freedom, social justice, equity, non-racism, non-sexism, the rule of law and reconciliation as critical to the instilment of a conducive culture of learning and teaching. (Lemmer, Meier \& Van Wyk 2006; Kivedo 2007). Banks (1992) on the other hand pronounces that the main aim of multicultural education is to reform the school and other educational practices and institutions in such a way that learners who reflect all types of diversity will endure educational equality and quality. These mentioned policy developments laid a platform for all schools to be declared 'open' to all learners, irrespective of race, creed or colour. Parents now had the opportunity to enroll their children at any school and were no longer governed by the previous system of demarcation based on racial and cultural lines. This move resulted in a process wherein large numbers of black learners moved away from township schools to previously Coloured, Indian and white schools. Coloured and Indian learners on the other hand, began an exodus to historically white schools. The integration of learners to historically white schools, however, did not take place without some daunting challenges. To this effect, Goduka (1999) protests that in spite of the diverse groups of learners, these previously white schools continued to function as mono-cultural schools. Learners with different backgrounds had to adapt to the European culture of the school. The curriculum of the schools was based on European traditions while learner expectations were grounded on the experiences of educators who were inadequately prepared to deal with diversity. Learners enter specific schools whose immediate contexts, histories, memories and commitments shape their organisation and practices (Banks \& Banks 1995).

Clearly, I contend that issues relating to the school climate and- culture in historically white school settings cannot be changed overnight, but that a constant awareness amongst the entire school population be created for the acknowledgement of diversity.

Lemmer, Meier and Van Wyk (2006) are of the view that priority issues emphasised within an integrated school context should be based on actions directed at eradicating injustice and inequality in society, whilst simultaneously focusing on the eradication of prejudice, intolerance and cultural misunderstandings amongst learners. I further argue that multicultural education should not to be internalised as a version of a divided education system; one that merely seeks to integrate and acculturate black learners into existing Euro-centric practices, without challenging educational, historical and psychosocial inequalities

In the wake of the above-mentioned which is also highlighted in the aim of this study, it becomes imperative to explore issues relating to integration and multicultural education. Furthermore, I contend that the underlying perceptions which white educators in historically white high schools hold, might be better understood within the context of the aforementioned constructs -this provides an opportunity to apply a social constructivist theoretical lens to understand the 
possible role and contribution of role players in desegregated school settings. According to Antherton, social constructivism emphasises how meanings and understandings grow out of social encounters (Antherton 2005) and are related to social interaction in the learning process, wherein educators and learners participate as equals in coconstructing learning opportunities. It is thus fitting for me as author of this paper, to validate my argument within this theoretical frame.

\section{Clarifying Key Concepts}

The concepts " integration" and " multicultural education" are now briefly discussed.

\subsection{Integration}

The post 1994 South African elections, introduced a process whereby all schools were open to all children. This led to a process of black flight from township schools, located in black residential areas, to those in white residential areas. This flight was, however only unidirectional. The influx of black learners to previously exclusively white schools led to the emergence of diverse races, cultures and religions in schools- a phenomenon for which educators had not been trained or prepared (Khosa 2000). The problem of de-racialisation and integration was exacerbated by the education policy prior to 1994. The apartheid education policy was aimed at brain-washing all races into believing that everything about blacks was inferior and of low quality and vice versa.

Soudien (2001) records the availability of very little research work done in post- apartheid South Africa on how learners are coping within their new school settings, and in particular how they are dealing with integration at predominantly, historically white schools. Furthermore, he argues that there seems to be a limited understanding of the complex relationship between school and identity and that this complexity applies both to the apartheid and postapartheid period. Fairclough (2004) also argues that teachers in white schools don't seem to have a fundamental understanding of the life worlds of black learners. According to him, the well known Brown vs Booard of Education Supreme Court decision in 1954 also laid the foundation for integration in American schools. Criticism made by both supporters and opponents of integration hold the view that the systematic discrimination left many black teachers, especially the older ones, ill educated and poorly trained and that the shake-up caused by integration might have raised standards. The scoring of low test scores by black learners in general, might have attached the notion of 'inferiority' to them.

\subsection{Multicultural Education}

Miller (2001) view multicultural education as an approach to school reform and transformation which is also directed to addressing social imbalances caused by inequalities perpetuated by discriminatory legislation. Multicultural education is not an ethnic or gender-specific movement but one which is designed to empower all learners to become knowledgeable, caring, critical and active democratic citizens in a racially polarized world (Clemons 2005). Lemmer, Meier and van Wyk (2006) argue further that multicultural education is about changing the nature of teaching and learning in order to create suitable and conducive teaching and learning environments for learners from diverse cultural backgrounds. Lynch in (Massey 1991) and Lemmer and Squelch (1993) hold the view that multicultural education refers to an education appropriate to a multicultural society in which there is legitimate acceptance and recognition of the diversity associated with cultural appurtenances which is premised on the dimensions of race, culture, creed, language, gender, class, religion, ability etc. It brings one to the realization that quality education and academic excellence amongst black learners in historically white schools cannot be fully realised without a consideration for educational equity.

The South African education context portrays similarities to what has been described around the afore-mentioned position to multicultural education. The heterogeneous nature of the South African society is duly reflected in the school setting, notably in historically white schools which are seemingly becoming more racially and culturally diverse. Educators in these classrooms, predominantly white, and indicative of the Northern Cape high schools, are now challenged by the teaching, managing and guiding of mostly black learners to meaningful learning experiences and equal opportunities. In most cases, these educators are unfamiliar with the socio-economic backgrounds, cultures, languages, context, life and world views of their learners. Multicultural education is about changing the nature of teaching and learning in order to create suitable and conducive teaching and learning environments for learners from diverse cultural backgrounds 


\section{The Problem Issue at Hand}

Various historically white high schools in the Northern Cape have enrolled a number of black learners and are therefore professing to practise multicultural education. The staff complement in most of the historically white schools may not necessarily reflect the cultural and linguistic diversity of the learners enrolled. In the Northern Cape, approximately 69\% of all learners registered at historically white high schools are black, while only $9 \%$ of the teaching staff is black (Northern Cape Department of Education, EMIS 2008). Kivedo (2006) and DFA (2002) argue that this state of affairs may result in racial misunderstandings and the consequent breakdown of educator-learner relations.

In a radical effort directed at deracialising the education system, the Gauteng Department of Education (GDE) in South Africa has cautioned historically white schools to employ at least $50 \%$ black teachers by 2005 as part of its equity plan. This directive is articulated as follows: "There are certain glaring inadequacies in these schools. Learners, mainly black, are almost exclusively taught by white teachers. The culture and environment in historically white schools (do) not promote transformation in line with the new democratic dispensation that promotes multiculturalism and positive appreciation of indigenous African and disempowered culture" (Independent Online, The Star 2001).

Against the background of the statement of problem, this study is aimed at assisting white educators in historically white high schools to fully comprehend their role, to understand the underlying pedagogical challenges which they face in integrated settings.

\section{Methodology}

\subsection{Participants}

With regard to the sample size of the population of this research, a total sample of $n=260$ white educators from 10 historically white high schools, representative of the 4 educational districts (Francis Baardt, Siyanda, Pixley Ké Seme and Namaqua) of the Northern Cape province were selected.

\subsection{Instruments}

A questionnaire survey was employed to investigate the perceptions of educators in historically white high schools with regard to school integration and its implication for multicultural education. The reasons for using a questionnaire are located in the fact that it is a widely used and a useful instrument for collecting survey information and for providing structured, often numerical data (De Vos, Strydom, Fouché \& Delport 2005; Gray 2004; Leedy \& Ormrod 2001). From the 260 questionnaires issued, a total of 241 educators (128 male and 113 females) completed and returned the questionnaires, thus ensuring a $92.3 \%$ response rate. In this case, a very high degree of validity was ensured. Section $A$ of the questionnaire survey dealt with the biographical information of the educators (gender, race, age teaching experience, academic qualifications, professional qualifications, rank, educational district, historical type of school and language in which the educator feels most comfortable to teach) while a 4-point Likert scale dealt with Section B (Perceptions of educators regarding school integration in multicultural contexts).

\subsection{Procedure and data analysis}

The provincial education authorities, educators, school principals and school governing bodies were informed about the aim of the study. All informed parties gave formal consent for the commencement of the study. In this study, the programme on statistical packages for the social sciences (SPSS) was used to analyse data

\section{Results and Discussion of Findings}

In terms of gender, the majority (53\%) of the educators in historically white schools in the Northern Cape province are male whilst $46,50 \%$ of the educators are females. This development may be attributed to the fact that males are in the majority in the high school section, which represents grades 8-12 (Northern Cape Department of Education, EMIS 2008). Relating to race, all participants involved in the study were white, although between 1-5\% of educators at historically white schools are of colour. In general, white educators are in the majority at these schools (Northern Cape Department of Education, EMIS 2008). Pertaining to teaching experience, the majority $(65,9 \%)$ of the participants' teaching 
experience ranges between 10 and 39 years. Those having teaching experience between 1 and 9 years were in the minority; namely $43.2 \%$. This tendency is a definite indication that most of the educators were trained in racially segregated training institutions, during the apartheid period and are therefore not fully trained for a multicultural teaching system. Additionally, these educators may find it extremely difficult to change their fixed and ingrained ways (McCray \& Gracia 2002; Johnson 2003). In terms of academic and professional qualifications, most participants (59,3\%) and (96, 7\%) declared that they were in possession of a B-degree and a teaching diploma. A concerted effort should nevertheless, be made to augment their training, as most of this training may have taken place in a mono-cultural school environment (Northern Cape Department of Education, EMIS 2008). Pertaining to rank, most of the participants (77\%) are on the rank of educator and only $21,6 \%$ formed part of the school management team. The role of both educators and the school management team plays a pivotal role in establishing multicultural education. Therefore, it has become necessary to review the manner in which educators and school management teams are trained and how their perceptions about multiculturalism are moulded (Meier 2005; Rios 1996). In terms of educational district, the vast majority (42\%) of the participants' teach in schools in the Frances Baard education district. This education district, being the largest, it could be expected that most historically white schools in the province would also be in this district (Northern Cape Department of Education, EMIS 2008). In terms of historical type of school, most participants' (94.1\%) are teaching in historically white schools. In spite of the fact that historically white schools have many black learners, the staff component has generally remained predominantly white. This implies that the education of black learners is grounded in the experiences of white educators who, initially, were never prepared to deal with diversity (Northern Cape Department of Education EMIS 2008; Erasmus \& Ferreira 2002). Relating to the language in which it is most comfortable to teach, the majority $(78,5 \%)$ of the participants' chose Afrikaans (One of the nine official languages of South Africa and medium of instruction) and only 15\% teach in English. This situation is of concern, as black learners constitute the majority at historically white high schools and receive their lessons in English. This situation invariably places black learners at a disadvantage, as educators will seldom display the same amount of confidence and flexibility when teaching in English, as when teaching in Afrikaans (Coutts 1992; Lemmer, Meier \& van Wyk 2006).

The results for section $B$ (White educators perceptions regarding school integration in multicultural contexts) of the questionnaire have been presented in the following tables 1 and 2 .

Table 1: Perceptions of educators regarding issues/aspects relating to multicultural education

\begin{tabular}{|c|c|c|c|c|c|c|c|c|c|}
\hline & & & $\begin{array}{l}\text { 1- } \\
\text { ongly } \\
\text { ree }\end{array}$ & & $\begin{array}{ll}2- \\
\text { gree }\end{array}$ & & agree & & $\begin{array}{l}\text { 4- } \\
\text { ongly } \\
\text { agree }\end{array}$ \\
\hline 1 & Items & $\mathrm{N}$ & $\%$ & $\mathrm{~N}$ & $\%$ & $\mathrm{~N}$ & $\%$ & $\mathrm{~N}$ & $\%$ \\
\hline 1.1 & $\begin{array}{l}\text { In my school the school climate is supportive of fostering healthy relations } \\
\text { between educators and black learners }\end{array}$ & 67 & 27.8 & 95 & 39.4 & 47 & 19.5 & 32 & 13.3 \\
\hline 1.2 & The racial representation of educators in my school enhances diversity & 37 & 15.4 & 39 & 16.2 & 73 & 30.2 & 92 & 38.2 \\
\hline 1.3 & $\begin{array}{l}\text { The teaching environment at my school prepares learners for citizenship in a } \\
\text { multicultural society }\end{array}$ & 48 & 19.9 & 51 & 21.2 & 59 & 24.5 & 83 & 34.4 \\
\hline 1.4 & Issues relating to multilingualism is promoted at my school & 42 & 17.4 & 36 & 14.9 & 76 & 31.5 & 87 & 36.1 \\
\hline 1.5 & $\begin{array}{l}\text { At my school a positive environment exists where educators and learners are } \\
\text { respectful of each others backgrounds }\end{array}$ & 51 & 21.2 & 48 & 19.9 & 69 & 28.6 & 73 & 30.3 \\
\hline 1.6 & $\begin{array}{l}\text { Educators at my school embrace a learning environment focused on providing } \\
\text { quality educational opportunities for all learners }\end{array}$ & 71 & 29.5 & 89 & 36.9 & 38 & 15.8 & 43 & 17.8 \\
\hline 1.7 & $\begin{array}{l}\text { The basic curriculum taught at my school allows me to address broader } \\
\text { societal issues during teaching }\end{array}$ & 47 & 19.5 & 52 & 21.6 & 69 & 28.6 & 73 & 30.3 \\
\hline 1.8 & I hold lower achievement expectations for my black learners & 58 & 24.1 & 69 & 28.6 & 61 & 25.3 & 53 & 21.9 \\
\hline 1.9 & I am aware of how my teaching methods influence my class effectiveness & 73 & 30.3 & 87 & 36.1 & 43 & 17.8 & 38 & 15.7 \\
\hline 1.10 & $\begin{array}{l}\text { In my school attempts are made to foster an acceptance for learners from } \\
\text { different cultural contexts. }\end{array}$ & 51 & 21.2 & 46 & 19.1 & 69 & 28.6 & 75 & 31.1 \\
\hline
\end{tabular}

Relating to item 1, the majority of the participants (67.2\%) hold the view that the school climate is supportive of fostering healthy relations between educators and black learners. This is a good sign of the intent of historically white schools to aspire in becoming inclusive. The omission of aspects which address multicultural educational issues may be detrimental and can influence the operation of the school programme negatively (Coutts 1992). It is noted with concern that $32.8 \%$ of the participants' have the opposite stance in terms of this item. It is evident in the analysis and from the literature review 
(Northern Cape Department of Education 2008) of the data, that $68.4 \%$ of the participants state that the racial representation of educators in their school doesn't enhance diversit (see item 1.2). The National Department of Education postulates that this trend needs to change at historically white schools and that a concerted effort should be made by the school management to recruit educators across the colour line. According to the Gauteng Department of Education (GDE) learners, mainly black, are almost exclusively taught by white teachers. The culture and environment of historically white schools do not implement the process of transformation in line with the new democratic dispensation that promotes multiculturalism and a positive appreciation of indigenous African and disempowered cultures (Independent Online-The Star 2001). Relating to item 1.3, most of the participants (58.9\%), pronounce that the teaching environment at their school are not preparing learners for citizenship in a multicultural society. On the other hand $41.1 \%$ of participants indicate a different view. It becomes crucial then, that these schools study and embrace relevant policy legislation such as the Constitution, the South African Schools' Act (SASA) and the National Education Policy Act (NEPA), so as to orientate educators and learners in the core values enshrined in these documents. Approaches to education such as multicultural education, education for social justice, liberal education, anti-racist and cross border pedagogies, may then be better interpreted by staff of ex-white schools (Cummins \& Dlamini 1997; Shimutwikeni 2010). Pertaining to Item $1.4,32.4 \%$ of the participants report that issues relating to multilingualism are promoted at their schools. In contract to the latter, $67.6 \%$ of the participants' allude to multilingual issues not being promoted at historically white schools, yet it can be argued that these schools have $69 \%$ of black learners (Northern Cape Department of Education, EMIS 2008). All educators attached to historically white schools need to be equipped to deal with the challenges of multilingualism in an ever-changing class situation, as most of them possess a low level of English (Alexander 1994; Sieghrun 2002). The National Department of Education's Language-in-Education policy document should be used as a guide to promote the use of more than one language in the school environment in historically white schools. Regarding item 1.5, $58.9 \%$ of the participants articulate a non- existence at their schools concerning a positive environment where educators and learners are respectful of each others backgrounds. An adequate teaching and learning culture needs to be created that encourages educators and learners to acquire the necessary knowledge, skills, values and attitudes to participate in meaningful ways in the classroom setting (Lemmer \& Squelch 1993; Massey 1991). Further it is also noted that $41.10 \%$ of participants affirm the existence of a positive environment where educators and learners are respectful of each others' backgrounds. This is a good indication that there are educators at historically white schools who understand the need to acknowledge diversity. In this regard, Adams (1991) and Alexander (2004) posit that educators in race and culturally diverse school contexts, such as in historically white schools, need to make a concerted effort to know and show an interest in the diversity of their learners; in other words they need to 'step outside themselves' and look for the habitual values, norms, beliefs and practices required to construct their own race and cultural backgrounds. Concerning item 1.6, the majority of respondents (66.4) indicate that they embrace a learning environment focused on providing quality educational opportunities for all learners. This is a constructive development towards having educators whom are focused on instilling inclusive classroom practices. Calitz (1992) views the development of decision making skills amongst staff members as a critical component in the realisation of a school's strategic objectives. It is for the principal and members of the School Management Team (SMT) to initiate thinking in their schools around the notions of quality education. Of concern is the $33.6 \%$ of participants who indicated that they are not supportive of a learning environment which embraces quality education opportunities for all learners. Item 1.7 reveals that $58.9 \%$ of the participants concur with the view that the basic curriculum taught at their schools allow them to address broader societal issues during teaching. If this is the case, it is thus a challenging and critical aspect that needs to be addressed. In the school curriculum certain important aspects regarding societal challenges are outlined. Harley and Wedekind (2002) concur with the above position and view the curriculum as a tool that should be constructed in such a way that it allows for the uniting all learners as equals in a democratic and prosperous school and classroom setting. Powers (2005) postulates that any curriculum based on the essentials of social justice and multicultural issues should be constructed in an innovative, well planned and coordinated way. The other $41.1 \%$ of participants are in agreement regarding the use of the curriculum in creating awareness about societal issues. Educators and learners will respect one another's diversity if societal challenges are more clearly articulated during the curriculum development processes (Shulz 2007). A total of 52.7\% participants as observed from item 1.8 have indicate they hold lower achievement expectations for black learners. This is of great concern, although the background to why this is the preferential choice of participants may be because of various reasons not known to this study. Multicultural education as an approach to education aspires to provide equal opportunities and quality education to all learners so that they can achieve optimally academically. However, the belief of multicultural education is that all learners irrespective of background and socio-economic status should be motivated by educators, especially in historically white schools where there is the perception by black parents 
that these schools are associated with good academic results. Lemmer et al. (2006) concurs with the latter view and are convinced that many white educators have low expectations of their black learners and tend to be more supportive and stimulating to their white learners, with the result that black learners underachieve. It is however also satisfying to observe that $47.3 \%$ of participants maintain they have high achievement expectations for black learners- this is a positive trend for the future of multicultural education in integrated school settings. Regarding item 1.9, the majority of participants $(66,4 \%)$ are aware of how their teaching methods influence their class effectiveness, whilst $(33,6 \%)$ are unaware of the influence of their teaching methods on class effectiveness. In ensuring that the level of skills, values and attitudes are acquired by learners during teaching, the educator should have a more holistic, formative and developmental approach to learning (Naicker 2000). There should not only be a focus on the 'how much of learning' but invariably also on 'how do learners learn?' and 'what do they learn?'. The minority (33.6\%) of the participants hold the view that they are unaware of the manner in which their teaching methods influence their class effectiveness. Effective educators reflect on their own practices and construct meaning-making opportunities, as a means of teaching learners from their own realities (Alexander 2004). Pertaining to item 1.10, the majority of the participants (59.7\%) are of the opinion that attempts are made in their schoos to foster an acceptance for learners from different cultures. McCarthy (1991) argues that multiculturism, especially as perceived by white educators in historically white schools, should attempt to promote cultural understanding and awareness about his/her class's cultural/ethnic groups. Educators should support learners to develop their cultural identities, their knowledge about other cultural groups and competence in one or more cultural systems. On the other hand, $40.3 \%$ of the participants indicate that they would like to have a better understanding of their class's cultural groups. This stance is in line with the aims and goals of multicultural education (Bennett 1990).

I now present and discuss another aspect (Value of Multicultural Education) of section B of the questionnaire via the use of the Factor Analysis method.

An exploratory factor analysis (EFA) was constructed because of its resistance to common threats to internal validity The measuring of sampling adequacy involves determining the suitability of individual variables for use in the factor analysis was evaluated using the Kaiser-Meyer-Olkin (KMO) (Gray 2004).

Table 2: Value of multicultural Education $(n=241)$

\begin{tabular}{|c|c|c|c|c|c|c|c|c|c|c|}
\hline & \multirow{2}{*}{$\begin{array}{c}X^{2} \\
\text { value }\end{array}$} & \multirow{2}{*}{$\begin{array}{c}\mathrm{p}- \\
\text { value }\end{array}$} & \multicolumn{2}{|c|}{$\begin{array}{c}\text { Very } \\
\text { important }\end{array}$} & \multicolumn{2}{|c|}{ Important } & \multicolumn{2}{|c|}{$\begin{array}{l}\text { Of little } \\
\text { importance }\end{array}$} & \multicolumn{2}{|c|}{ Unimportant } \\
\hline & & & $F$ & $\%$ & $F$ & $\%$ & $F$ & $\%$ & $\mathrm{~F}$ & $\%$ \\
\hline $\begin{array}{l}2.1 \text { Accommodate the co-existence of different ethnic, cultural and } \\
\text { language groups in the class setting }\end{array}$ & 1 & 0.628 & 142 & 58.9 & 66 & 27.4 & 23 & 9.5 & 10 & 4.2 \\
\hline $\begin{array}{l}\text { 2.2 Acknowledge the fact that each group wants to preserve its } \\
\text { own unique identity and aspects relevant to its culture }\end{array}$ & 1 & 0.586 & 110 & 45.6 & 82 & 34.1 & 36 & 14.9 & 13 & 5.4 \\
\hline $\begin{array}{l}\text { 2.3 Reducing culturally biased behaviour, prejudice and } \\
\text { stereotyping amongst learners and myself. }\end{array}$ & 1 & 0.735 & 133 & 55.2 & 81 & 33.6 & 18 & 7.5 & 09 & 3.7 \\
\hline $\begin{array}{l}\text { 2.4 Helping learners to explore ways to expand their contact/ } \\
\text { communication with other race and cultural groups. }\end{array}$ & 1 & 0.698 & 97 & 40.2 & 69 & 28.6 & 42 & 17.5 & 33 & 13.7 \\
\hline $\begin{array}{l}2.5 \text { Promote and aspire to quality and effective education for all } \\
\text { learners. }\end{array}$ & 1 & 0.719 & 87 & 36.1 & 53 & 21.9 & 58 & 24.1 & 43 & 17.9 \\
\hline $\begin{array}{l}\text { 2.6 Ensure and lobby for equal opportunities for all learners, } \\
\text { irrespective of race, culture, colour, religion, etc. }\end{array}$ & 1 & 0.653 & 113 & 46.8 & 69 & 28.6 & 31 & 12.9 & 28 & 11.7 \\
\hline $\begin{array}{l}2.7 \text { Develop the intellectual, social and personal skills of all } \\
\text { learners optimally. }\end{array}$ & 1 & 0.599 & 121 & 50.2 & 74 & 30.7 & 19 & 7.9 & 27 & 11.2 \\
\hline
\end{tabular}

The difference is statistically significant if $\mathrm{P}<0.05$

Table 2 demonstrates that the significance of the p-values "value of multicultural education" as all greater than 0.05 and is therefore not statistically significant. The suitability of the KMO for individual variables for use in the factor analysis which is aimed at measuring the sampling adequacy of seven items in the questionnaire. A KMO-value which is greater than 0.5 , indicates that the variable is significant at that level. The KMO-values relating to the value of multicultural education are included in the factor analysis which are presented in Table 2 (this KMO value scale was used: 0.90 to $1.00=$ marvelous or 0.80 to $0.89=$ meritorious or 0.70 to $0.79=$ middling or 0.60 to $0.69=$ mediocre or 0.50 to $0.59=$ miserable and 0.000 to $.0 .49=$ don't factor).

Participants conceded that they considered at least three items to be significant to the 'value of multicultural 
education'. The discussion for these three items will be based on the literature by Bennett (2007), Erasmnus and Ferreira (2002), Gollick and Chinn (2002), Lemmer et al. (2006), Schlebush (in Lemon 1999), Kivido (2007) and Alexander (2004).

In terms of 2.1, participants (58.9\%) view the co existence of different ethnic, cultural and language groups in class settings as an important value of multicultural education. A response to item 2.1 may be pluralistic in the sense that it recognises the diverse racial and cultural groups in society and does not denigrate them simply because they deviate from white middle-class patterns of behaviour. Integrated pluralism affirms the equal value of the school's various ethnic groups, encouraging their participation, not on majority-defined terms, but within an evolving system which reflects the contributions of all groups. Integrated pluralism goes beyond mere support for the side-by-side coexistence of different group values and styles, but is integrationist in the sense that it affirms the educational value inherent in exposing all learners to a diversity of perspectives and behavioural repertoires. The social value of structuring the school so that learners from previously isolated and even hostile groups can come to know one another under conditions conducive to the development of positive inter-group relations. Interrelated pluralism takes an activist stance in attempting to foster interaction between different groups of learners, rather than accepting re-segregation as either desirable or inevitable.

Relating to Item 2.3 . the majority of the participants $(55,2 \%)$ are of the opinion that reducing culturally biased behaviour, prejudice and stereotyping amongst learners and themselves is a very important value of multicultural education. Combating racism, sexism, prejudice, and discrimination means lessening negative attitudes and behaviours based on gender bias and misconceptions about the inferiority of races and cultures which are different from one's own. The emphasis should be on the clearing up of myths and stereotypes associated with gender, different races, and ethnic groups. Basic human similarities are thus stressed during this corrective process with the goal being to develop antiracist, anti-sexist behaviour based on the awareness of the historical and contemporary evidence of individual, institutional and cultural racism and sexism.

Pertaining to Item 2.7, more than half of the participants (50.2\%) view the optimal development of learners' intellectual, social and personal skills as cardinal values of multicultural education. Personal and social action skills include the knowledge, attitudes, and behaviours needed to help resolve major problems that threaten the future of the planet and the well-being of humanity. One emphasis is on thinking globally and acting locally; the aim being to develop a sense of personal and political efficacy and global responsibility resulting in a participatory orientation among adult members of society. A further emphasis should be placed on enabling minorities and non-minorities to become change agents through democratic processes. Moreover, ever-increasing evidence suggests that an economic system depends fundamentally on a generally well-educated population equipped with the relevant competencies and skills required in the economy at any point in time, as well as the capacity to continue learning and developing new skills and acquiring new competencies.

In the above discussion we attempted to demonstrate the value of multicultural education, not only for integrated schools settings such as the historically white schools. of the Northern Cape Province but for all types of schools. After all, the aim and purpose of multicultural education is to bring about equality in all spheres of society and to respond to challenges relating to quality and effective education.

\section{Recommendations}

In the wake of the purpose of this study, I propose the following recommendations:

\subsection{Becoming knowledgeable about multicultural education}

In relation to this, Erasmus and Ferreira (2002) argue that tolerance in itself is insufficient, as it indicates a mere endurance of and not necessarily respect for other cultures. It would seem that the solution involves a change of attitude towards, rather than only the acquisition of knowledge about other cultures. Furthermore, multicultural education should not only be treated as a series of isolated experiences; rather, it should form part of the curriculum, whilst educator training should incorporate multicultural awareness, knowledge and skills as part of the educator's course.

Modules and courses on multicultural education should be made compulsory in teacher-training programmes at institutions of higher learning. The initial focus should be on persuading student-teachers to actively assess their perceptions of learners from diverse backgrounds. It therefore becomes necessary that all educators be provided with adequate, appropriate and effective training and guidance in all the aspects of multicultural education. In South Africa, this lack of multicultural teaching skills, together with the cant africanisation of learning content has led to widespread 
discontent among white educators in South African schools (Beeld 2004). Educator discontent may again have an adverse effect on the manner in which these educators interact with their black learners in the classroom situation, resulting in possible (black) learner dissatisfaction.

\subsection{Trans-disciplinary knowledge production for diverse school settings}

Any knowledge production process, whether at school, university, home or community should be relevant to the social and economic needs of South Africa (Winburg 2006). From the survey, it could further be deduced that learners from diverse multicultural groups may continue to present challenges to multicultural schools and those providing educational and support services. The development of educational curricula that enhance awareness, knowledge and skills for learners is vital if these schools are to provide culturally relevant, respectful and affirming teaching environments. To that end, the development of culturally sensitive pedagogies, teaching methods, learning and intervention strategies, as well as professional training, needs to take place. It is important that the latter actions should be structured along the lines of knowledge, skills development and an awareness of diversity. In relation to the hands-on practical activities as an instructional strategy, Moore, Madison-Colmore and Collins (2005) advise that learners should become acclimatized to content on diversity through the early exploration of issues of diversity and self-reflecting activities and exposure to meaning-making opportunities. Equipping the school management teams in integrated schools with the necessary strategies to celebrate this diversity should be an indispensable necessity.

\subsection{Education for social justice}

Social justice should be on the agenda of any attempt aimed at transforming schooling. .Educational opportunities which seek to include all learners create multiple opportunities for educators and learners to experience diverse views and people on a daily basis and to converse about difference, human rights and social justice. Neither recognition nor redistribution of resources as a means of addressing socio-economic inequalities alone, can make education more socially just; learners also require both respect and adequate social goods to develop holistically and pursue and achieve their academic and lifelong goals (Lynch \& Baker 2005).

\subsection{Historically white school settings}

Lemmer et al. (2006) appropriately point out that culture, race, and social class are used to construct the major groups of people in society. Thus, educators, especially in integrated schools, need to understand how the ascribed characteristics of culture, race and class may influence their understanding of learners. It may be important to consider these characteristics collectively and not separately, since all learners are members of all three status groups. It is this simultaneous membership of all these groups that influences learners' perceptions and actions. This challenge may be addressed if a concerted effort is made by school management teams to recruit the best qualified, experienced and 'fitting profile' educators of colour. I'm not saying that competence and quality should be jeopardised in the process, but I contend that these schools should reflect the diversity of the learner population.

\section{Conclusion}

This study was by no means pursued to racialise issues pertaining to the operation of historically white schools in the Northern Cape province. These schools are in fact, delivering in terms of their academic mandate and I'm convinced that they have good practices to share with underperforming schools in the region. However, issues of social justice and notions concerning multicultural education need to be seriously interrogated in integrated school contexts. I further contend that South Africa needs citizens that are not only academically up to the demands and challenges being presented, but need citizens who can make a holistic contribution to the common cause of society. In conclusion, any process aimed at integration in historically white schools in the Northern Cape need to be facilitated via thorough planning by education authorities and through consultation with all relevant role players. 


\section{References}

Abdi, A.A.(2001). Integrated education and black development in post-apartheid South Africa: critical analysis. Compare, 31(2), 229244.

Adams, B.S., Pardo, W.E. \& Schniedewind, N. (1991). Changing "The way things are done around here". Educational Leadership, 3940.

Alexander G. (2004). The design and evaluation of a staff development programme for amalgamated schools in the Northern Cape. Unpublished Ph. D Thesis. Bloemfontein. University of the Free State.

Alexander, N. (1994). Language planning for a multilingual South Africa. Johannesburg: Heinemann.

Antherton, J.S. (2005). Learning and teaching: Piaget's developmental theory. [Online] Available: http://www.learningandteaching.info /learning/piaget/constructivism.htm (July 15 2013)

Banks, J.A. (1992). Reducing prejudice in children: Guidelines from research. Social Studies and the Young Learner , 5(2), 3-5.

Banks, J.A. \& Banks, C.A.M. (1995). Handbook of Research on Multicultural Education. New York: Simon and Schuster Macmillan.

Beeld (2004). 10 jaar se strewe na onderwysheid. Beeld 20 April: pg.11.

Bennett, C. (1990). Comprehensive multicultural education. Theory and Practice (2nd ed.). Boston. Allyn \& Bacon.

Bennett, C. (2007). Comprehensive Multicultural Education (6th ed.). Boston: Allyn \& Bacon.

Calitz, L., Viljoen, J., Moller, J. \& Van der Bank, A. (1992). Effective school management. Pretoria: Via Afrika Limited.

Clemons, S. (2005). Developing multicultural awareness through designs based on family cultural heritage: Application, impact and implications. International Journal of Art \& Design, 288-297.

Coutts, A. (1992). Multi-Cultural education: The Way Ahead. Pietermaritzburg: Shuter and Shooter

Cummins, J. \& Dlamini, S.N. (1997). What might a critical pedagogy of ESL look like? Paper presented at the TESOL Annual Conference (Orlando, Florida, July 1997)

De Vos, A.S., Strydom, H., Fouche, C.B. \& Delport, C.S.L. (2005).Research at grass roots for social sciences and human service professions. Pretoria: Van Schaik.

Diamond Fields Advertiser. (2002). Allegations of racism at Rietvale high school. DFA 14 April: pg. 11.

Erasmus, P. \& Ferreira, G.V. (2002). Black Grade 9 learners in historically white suburban schools and their experience of integration. South African Journal of Education, 22 (1): 28-35.

Fairclough, A. (2004). The costs of Brown: Black teachers and school integration. The Journal of American History, 43-55.

Goduka, I.N. (1999). Indigenous epistemologies - ways of knowing: affirming a legacy. South African Journal of Higher Education, 13(2), 26-35

Graye, E. (2004). Doing Research in the Real World. SAGE Publications: London.

Harley, K. \& Wedekind, V. (2002). Political change, curriculum change and social transformation, 1990 to 2002. International Journal of Education Development, 20 (4), 287-304.

Independent Online. (2001). Hire black teachers, schools told. The Star, 24 June: pg. 1-2.

Johnson. L. (2003). Multicultural policy as social activism: redefining who 'counts' in multicultural education. Race, Ethnicity and Education, 6(2), 107-121.

Gollnick, D. \& Chinn, P.C. (2002). Multicultural education in a pluralistic society, (2nd ed.). New Jersey: Merrill.

Jansen, J.D. (2005). Race and Restitution in Education Law and Policy in South Africa and the United Statesof America. In: C. Russo, J. Beckmann and JD Jansen (eds), Equal

EducationalOpportunities: Comparative Perspectives in Education Law. Pretoria, Van SchaikPublishers (pp. 270-283).

Kanpol, B. \& McLaren, P. (1995). Critical Multiculturalism. Uncommon Voices in a Common Struggle. London: Bergin and Garvey.

Kivedo, C.L. (2006). A psycho-educational investigation into the state of multicultural education and the design of a multicultural frame work for Northern Cape schools. Unpublished Ph.D thesis. Bloemfontein. University of the Free State.

Khosa, R. (2000). De-racialisation and Integration in South African Schools: Challenges, Initiatives and Opportunities. United Kingdom: University of Cambridge

Leedy, P.D. \& ORMROD, J.E. (2001) Practical Research. Planning and design, (7thed.) Upper Saddle River: Prentice Hall.

Lemmer, E. \& Squelch, J. (1993). Multi-Cultural Education: a teacher's Guide. Halfway House: Southern Book uitgewers.

Lemmer, E.C. , Meier, C. \& Van Wyk, J.N. (2006). Multicultural Education. An educator's manual. Pretoria: Van Schaik Publishers.

Lemon. A . (2004). Redressing school inequalities in the Eastern Cape, South Africa: Journal of Southern African Studies, 30(2), 269 290.

Lynch, K. \& Baker, J. (2005). Equality in education: An equality of condition perspective. Theory and Research in Education , 3, 131164.

Massey, I. (1991). Developing anti-racist multicultural education in schools. More than skin deep. London: Routledge \& Kegan Paul.

McCarthy, C. (1991). Multicultural approaches of racial inequality in the United States. Oxford Review of Education, 17(3), 308-310.

McCray, A. \& Garcia, S. (2002). The stories we must tell: developing a research agenda for multicultural and bilingual special education. Qualitative studies in Education , 15(6), 599 -612.

Mda, T. (2000). Critical Issues in South African Education after 1994. South Africa: Juta and Company.

Meier, C. (2005). Addressing problems in integrated schools: learner's teachers' perceptions regarding viable solutions for learners` academic problems. South African Journal of Education, 25(3), $170-177$.

Miller, D.M. (2001). Principles of social justice. Cambridge: Harvard University Press. 
Moore, S., Madison-Colmore, \& Collins, W. (2005). Appreciating Multiculturalism: Exercises For Teaching Diversity. Journal of African American Studies, 8(4), 63-75.

Naicker, S.M. (2000). From Apartheid to Inclusive Education: The challenges for transformation. Paper presented at the International Education Summit for a Democratic Society (Wayne State University, Michigan, U.S.A, 26 June-28 June 2000).

Northern Cape Department of Education. (2008). Education Management and Information Services (EMIS). Northern Cape.

Powers, P.K. (2005). Cultural property and student identity in the multicultural classroom. Melus 30 (2), 49-64.

Republic of South Africa (RSA). (1996). The Constitution Act No. 108. (Vol. 398, No. 17678). Pretoria: Government Printer.

Republic of South Africa (RSA). (1996). National Education Policy Act No. 27 of 1996. (Vol. 370, No. 17118). Pretoria: Government Printer.

Republic of South Africa (RSA). (1996). South African Schools Act No. 84 of 1996. (Vol. 377, No. 17579). Pretoria: Government Printer.

Rios, F. (1996). Teacher thinking in cultural contexts. New York: Suny Press.

Schulz, D. (2007). Stimulating social justice theory for service-learning practice. In:Calderón, J. Z. (Ed.),

Race, poverty, and social justice: Multidisciplinary perspectives through service learning (pp. 23:35). Sterling, VA: Stylus Publishing.

Shimutwikeni, H. (2010). Social Education. IRAWA. Official University of the Free State student newspaper, 65 (9), 7.

Sieghrun, A. (2002). A scenario for indegenous minority education in South Africa: the case of Schmidtsdrift San Combined School. Perspectives in Education, 20(1), 141-150.

Soudien, C. (2001). Certainty and ambiquity in Youth identities in South Africa: discourses in transition. Discourse: Studies in the Cultural Politics of Education, 22 (3), 311-326.

Van der Walt, J.L. (1994). Multicultural education for South Africa. Multicultural education: New challenges for South Africa. Faculty of Education, Potchefstroom University for Christian Higher Education.

Winburg, C. (2006). Undisciplining knowledge production: Development driven higher education in South Africa. Higher Education, 51, $159-172$. 